\title{
The interplay of marketing and design
}

\author{
Jörg Henseler ${ }^{1,2}$ (D) Manuela Guerreiro ${ }^{3}$ (D) Nelson de Matos ${ }^{4}(\mathbb{D}$
}

Received: 30 March 2021 / Accepted: 14 April 2021 / Published online: 28 May 2021

(c) The Author(s) 2021

\begin{abstract}
This paper provides insights into the interdisciplinary intersections between marketing and design. It explores the various design intersections in the marketing fields. The collaboration between marketing and design is restricted by the paradigm boundaries, but not by the industry, researchers, and research projects. Challenges for both disciplines' future are explored, highlighting the need for a paradigm shift in marketing.
\end{abstract}

Keywords Marketing · Design · Theoretical framework · Empirical research

\section{JEL Classification M31}

\section{Introduction}

In the marketing discipline's early days, when the business practice of marketing was about to turn into a profession (Brown 1948), marketing could be conceived of as a kind of design. A marketing executive was then typically seen as a designer of marketing instruments, as"... a 'mixer of ingredients,' who sometimes follows a recipe prepared by others, sometimes prepares his recipe as he goes along, sometimes

Jörg Henseler

j.henseler@utwente.nl

Manuela Guerreiro

mmguerre@ualg.pt

Nelson de Matos

nelsonmatos@gmail.com

1 University of Twente, Drienerlolaan 5, 7522 NB Enschede, The Netherlands

2 NOVA Information Management School, Universidade Nova de Lisboa, Campus de Campolide, 1070-312 Lisbon, Portugal

3 Cinturs - Research Centre for Tourism, Sustainability and Well-being, Faculty of Economics, Universidade do Algarve, Campus das Gambelas, 8005-139 Faro, Portugal

4 Cinturs - Research Centre for Tourism, Sustainability and Well-being, School of Management, Hospitality and Tourism, Universidade do Algarve, Campus da Penha, 8000-139 Faro, Portugal 
adapts a recipe to the ingredients immediately available, and sometimes experiments with or invents ingredients no one else has tried" (Banting and Ross 1973, p. 1). Since the early 1950s, marketing scholars have been addressing and exploring the essence of marketing (e.g., Hutchinson 1952) and pondering whether marketing is a science or a body of thought. Marketing has since gained its scientific recognition (Bartels 1951) and moved away from the traditional "final purchase and sale of a product or service" (Kotler and Levy 1969, p. 55). Marketing scholars laid the theoretical foundations (e.g., Hutchinson 1952; Bartels 1968) and reached out to several multidisciplinary fields (Kotler and Levy 1969), despite some critique (e.g., Luck 1969). Among these, new areas were the object of research interest from various scholars, addressing for instance industries and organizations, the third sector (Kotler and Murray 1975), and non-profit organizations (Shapiro 1974). Moreover, scholars turned their attention to aesthetics (Levy and Czepiel 1974), arts (Mokwa et al. 1980; Peterson 1980), and the design of products (Choffray and Lilien 1978). But although marketing was touching base with design topics, it mostly lost its own design orientation. Instead, the transaction or exchange view of marketing became the discipline's dominant perspective (c.f., Bagozzi 1974). When the global economy was expanding, customer satisfaction and enduring relationships became essential to competitiveness and success (Berry 1995). At the same time, the development of information and communication technologies (ICT) increased the market changes (Alves et al. 2016), especially about consumers' relationships, with brands and other people (Laroche et al. 2013). Not only did ICT change the market, but it also served as an essential enabler for new marketing techniques-centred around design and new information systems (Graesch et al. 2020). Social Networks' success is an example that highlights the relevance of consumers' attachment to interpersonal interactions (de Wulf et al. 2001) and how design influences it (Beverland et al. 2017; Gilal et al. 2018). Yet, there is even another way how information systems impact the marketing discipline, namely as an opportunity to bring back marketing's initial design-orientation. Due to its partial origins in computer science, information systems research is a pioneer in awareness that design is an integral part of the discipline (Österle et al. 2011). Nevertheless, despite the significant growth of marketing and design research over the last decades of the twentieth century (Bloch 2011), recognition of the importance of design to marketing by scholars and practitioners (Beverland 2005; Krohn 2015; Luchs et al. 2016) came long after Kotler and Rath (1984) had identified design as a strategy tool.

\section{Marketing and design}

Marketing and design are present in every aspect of our daily routine and way of life. Marketing and design are about customers and for customers, sharing common ambitions in offering better market products and services. Design is a practice-based approach developed as a process and emphasizes meaningful solutions (Archer 1981; Brown 2008; Cross 1982). In effect, earlier studies analyze the role and the impact of design on customers' behavioural intentions from numerous disciplinary perspectives (Walsh 1996). These studies highlight the design capacity to open new 
markets and renovate older ones (Bruce and Daly 2007). There is thus ample reason to shed more light on the intersections of marketing and design. For the intersections between design and marketing to thrive, change must occur, and discussion must be encouraged.

In October 2018, the First International Conference on Marketing and Design (ICMD 2018) organized by several international scholars, including the authors, took place at the University of Algarve, Portugal. ICMD is a stage for scholars and practitioners' debate on the interplay of marketing and design. In the scope of this conference, two calls for papers for special issues were open: (1) a call for papers addressing "Design and Marketing: intersections and challenges" in Creativity and Innovation Management, resulting in eleven papers being published; (2) a call for papers in "Marketing and Design: intersections and challenges" in this journal, resulting in six papers being selected after a rigorous reviewing process.

\section{Six studies addressing marketing and design intersections}

This special issue offers some insight into the interplay between marketing and design. The six selected papers come from different academic backgrounds, geographies, and perspectives, thus demonstrating the topic's robustness and interest. It explores different perspectives and presents several intersections, providing a stateof-the-art regarding the topic. In effect, each paper provides insights into the composite and complex nature of marketing and design and reinforces the need to look at the markets and consumers from a new standpoint. As such, six key insights are provided.

Key insight 1: New Design-driven Innovation strategies can be developed and found in the creative sector.

The contribution titled "Cultural Product Innovation Strategies Adopted by the Performing Arts Industry" by Chun Liang Chen examines the creative sector on how to create value using a design-driven innovation approach to sustain a competitive advantage. His findings in the puppetry sector showed that by using functionality and meaning, firms could design and develop four types of innovation practices: market-pull, technology-push, design-driven, and a mixture of technology-push and design-driven. Their paper extended existing models and proposed new product management practices that emphasized the role of traditional and design features, along with design-driven innovation.

Key insight 2: The experience proposition of the brand can be conceptualized into a four-iteration cycle brand experience manual.

In the paper entitled "Brand experience manual: Bridging the gap between brand strategy and customer experience" Mauricy Motta-Filho offers a customer experience-centric approach to branding. He describes the process through a four-iteration cycle on how to communicate the brand experience proposition. The author develops the brand experience manual to help experienced managers create and deliver impactful brand experiences to customers.

Key insight 3: Design influences mobile tourism apps usage and acceptance at the destination. 
In the paper entitled "Do tourism applications' quality and user experience influence its acceptance by tourists?", Pedro Palos-Sanchez, José Ramón Saura, and Marisol B. Correia applied the Unified Theory of Acceptance and Use of Technology 2 to assess the customers' behavioural intention to use tourism apps. They also verified the influence of design and user experience on mobile tourism apps usage and acceptance. Authors found that the demographic profile can be a crucial predictor of tourism apps adoption and use on mobile devices.

Key insight 4: Shopping companions' traits and behaviours influence retail shoppers.

Tobias Scholz, Jörn Redler, and Sven Pagel, in their article with the title "ReDesigning adaptive selling strategies: the role of different types of shopping companions" looked at the influence of shopping companions in retail sales. The authors used a qualitative approach to systematize in-depth interviews with salespeople to identify shopping companions' character traits and behaviours. Based on these findings, they discuss how adaptive selling strategies could be re-designed.

Key insight 5: Designer cues influence consumers' outcomes.

In the paper titled "A qualitative approach to designer as a product cue: Proposed conceptual model of consumers perceptions and attitudes" Elif Idemen, Ayse Banu Elmadag, and Mehmet Okan studied the effects of product cues. They found four distinct categories of consumers' responses to designers as product cues. These cues are related to the product and the consumption context and the consumers and the designer's characteristics. The authors proposed a conceptual model incorporating and integrating multiple processing routes (emotional and cognitive) towards designer cues' influence and outcomes on consumers.

Key insight 6: Confirmatory composite analysis is a statistical method for confirmatory marketing and design research that models abstract concepts using emergent variables.

In the paper titled "Confirmatory composite analysis using partial least squares: setting the record straight," Florian Schuberth presents a novel statistical method that is suitable for confirmatory research at the intersection of marketing and design research: confirmatory composite analysis. Confirmatory composite analysis was invented by Jörg Henseler and Theo K. Dijkstra and aims at testing whether a composite of more elementary parts serves as an emergent variable (Henseler and Schuberth 2020), which means that it acts as a whole. Unfortunately, Hair et al. (2020) confounded confirmatory composite analysis with the measurement model evaluation step of partial least squares structural equation modeling. Schuberth (2021) disentangles both techniques and compares them. Whereas confirmatory composite analysis turns out to be a useful technique for its intended purpose, the other method does not seem to live up to its claims.

Additional new insights were provided by the eleven papers published in the sister special issue. Table 1 lists all 17 papers and their key insights. 
Table 1 New insights on the interplay of marketing and design

\begin{tabular}{|c|c|}
\hline Study & Insight \\
\hline Chen et al. (2021) & $\begin{array}{l}\text { New design-driven Innovation strategies can be developed and } \\
\text { found in the creative sector }\end{array}$ \\
\hline Motta-Filho (2021) & $\begin{array}{l}\text { The experience proposition of the brand can be conceptualized } \\
\text { into a four-iteration cycle brand experience manual }\end{array}$ \\
\hline Palos-Sanchez et al. (2021) & $\begin{array}{l}\text { Design influences mobile tourism apps usage and acceptance at } \\
\text { the destination }\end{array}$ \\
\hline Scholz et al. (2021) & $\begin{array}{l}\text { Shopping companions' traits and behaviours influence retail } \\
\text { shoppers }\end{array}$ \\
\hline Idemen et al. (2021) & Designer cues influence consumers' outcomes \\
\hline Schuberth (2021) & $\begin{array}{l}\text { Confirmatory composite analysis is a statistical method for con- } \\
\text { firmatory marketing and design research that models abstract } \\
\text { concepts by means of emergent variables }\end{array}$ \\
\hline Mulder-Nijkamp (2020) & $\begin{array}{l}\text { When designers design brand extensions, they should ensure } \\
\text { fit with the parent brand and increase the brand extension's } \\
\text { novelty without sacrificing its typicality }\end{array}$ \\
\hline Xue and Swan (2020) & $\begin{array}{l}\text { The effect of design capabilities on innovations is contingent on } \\
\text { technology and the market }\end{array}$ \\
\hline Hemonnet-Goujot et al. (2020) & $\begin{array}{l}\text { There are three types of collaboration between external design } \\
\text { and marketing: (1) collaborations characterized by a strong } \\
\text { marketing lead that rely on customer-based designers, }(2) \\
\text { collaborations described by a strong design lead that rely on } \\
\text { process-based designers, and (3) collaborations } \\
\text { making use of cobranding with star designers }\end{array}$ \\
\hline Overdiek and Warnaby (2020) & $\begin{array}{l}\text { Consumer engagement observable in pop-up stores facilitates } \\
\text { co-design and gives marketers insight into what is meaningful } \\
\text { to consumers }\end{array}$ \\
\hline Huertas and Pergentino (2020) & $\begin{array}{l}\text { Consumer cocreation claims have more impact on customers' } \\
\text { purchase intentions if there is negative information on product } \\
\text { category performance }\end{array}$ \\
\hline Sette and Brito (2020) & $\begin{array}{l}\text { Digital influencers not only express many conventional dimen- } \\
\text { sions of creativity, but } \\
\text { also, a new attribute dubbed originality }\end{array}$ \\
\hline Coco et al. (2020) & $\begin{array}{l}\text { Novices in design thinking such as marketing and business stu- } \\
\text { dents face three struggles during a design thinking innovation } \\
\text { journey: destabilizing, non-deciding, and abstracting }\end{array}$ \\
\hline Baumgarth and Bahati Wieker (2020) & $\begin{array}{l}\text { Urban art, such as street art and graffiti, positively affects con- } \\
\text { sumers' product evaluation }\end{array}$ \\
\hline Nagel and Schumann (2020) & $\begin{array}{l}\text { Consumers' perceptions of the innovative aesthetic value buffer } \\
\text { the effect of product-related hedonic experience on attitudes } \\
\text { toward the product }\end{array}$ \\
\hline Carvajal Pérez et al. (2020) & $\begin{array}{l}\text { Creative heritage-a type of cognitive resource-can help } \\
\text { marketing and design teams in luxury organizations to address } \\
\text { destructive and creative tensions and overcome the trade-off } \\
\text { between product innovativeness and brand consistency }\end{array}$ \\
\hline Artusi and Bellini (2020) & $\begin{array}{l}\text { To embody new meaning in a new service, the service concept } \\
\text { must be simple and focused on one concrete element in the } \\
\text { customer journey, the so-called "Moment of Meaning" }\end{array}$ \\
\hline
\end{tabular}




\section{Marketing and design future challenges}

The papers in this special issue remind the challenges that lie in finding and understanding the two areas' synergies. In effect, marketing theory needs to expand and re-evaluate the inclusion of design as a critical concept. A paradigm shift of the same dimension as McCarthy's (1978) marketing mix is needed to combine both paradigms, design and marketing (Henseler 2017). Despite the existing literature recognizing fruitful research avenues (Alfakhri et al. 2018; D'Ippolito et al. 2014; Creusen and Schoormans 2005; Rothwell and Gardiner 1983), marketing and design intersections are not yet clear, and the development of new methodologies is at its infancy. We believe a paradigm shift is needed, one in which practitioners and researchers ask how design can contribute to and influence marketing knowledge (and the inverse is also relevant). For instance, Beverland (2005) mentioned how uneasy the relationship between marketing and design could be. Moreover, design management processes and activities need to be further investigated (Bruce and Daly 2007), and new approaches to combine both paradigms and reduce their differences are essential (Henseler 2017).

This special issue contributes to the debate, with the six studies showing how design and innovation can be drivers for new product development in the cultural and creative sector. From a research perspective, new opportunities for collaboration between marketing, culture, and arts are highlighted. Firms have adopted design processes as a strategy and as instruments for innovative practices and products (Berkowitz 1987; Kumar 2009). We believe the digital transformation and managerial practices require more creative and innovative design approaches, relying on empirical and theoretical advancements to understand consumers and their behaviours. Two of the studies offered an answer on how brands can engage customers during experiential events and how design impacts apps' success, and how it influences users' behaviour. Noteworthy is the finding that the digital sector industry is already enabling customers to define their preferences (e.g., cloud-based design) and choices (Liu et al. 2020; Wu et al. 2015). In particular, one paper stressed how shopping companions influence shopping situations, recommending different customer orientation of salespeople. Another paper has highlighted how one customer may accept different methods, forms, images, but they may be unappropriated to another. Researchers need openness to design and marketing intersections because designer cues and communicating design represent a vital form of non-verbal communication.

Moreover, it is one form of communication that conveys meanings and emotions to users clearly and distinctly. Finally, the last article offers confirmatory composite analysis to assess composite models, a promising methodology for confirmatory research at the intersection of both disciplines. We believe this special issue clarifies the structural changes that need to occur between marketing and design. In effect, we hope it may serve as an input to reinforce the design's presence in products and services and how we see, think, act, and relate to others.

Acknowledgements The authors would like to thank RMSC's co-editor in chief Ralf Ewert for all the support and encouragement. The article publishing charge was funded by the University of Twente. No other particular funding was made use of. 
Funding This research was funded by National Funds provided by FCT-Foundation for Science and Technology through projects UIDB/04020/2020.

Availability of data and materials Not applicable.

\section{Declarations}

Conflict of interest Not applicable.

Ethics approval Not applicable.

Consent to participate Not applicable.

Consent for publication Not applicable.

Open Access This article is licensed under a Creative Commons Attribution 4.0 International License, which permits use, sharing, adaptation, distribution and reproduction in any medium or format, as long as you give appropriate credit to the original author(s) and the source, provide a link to the Creative Commons licence, and indicate if changes were made. The images or other third party material in this article are included in the article's Creative Commons licence, unless indicated otherwise in a credit line to the material. If material is not included in the article's Creative Commons licence and your intended use is not permitted by statutory regulation or exceeds the permitted use, you will need to obtain permission directly from the copyright holder. To view a copy of this licence, visit http://creativecommons.org/licen ses/by/4.0/.

\section{References}

Alfakhri D, Harness D, Nicholson J, Harness T (2018) The role of aesthetics and design in hotelscape: a phenomenological investigation of cosmopolitan consumers. J Bus Res 85:523-531

Alves H, Fernandes C, Raposo M (2016) Social media marketing: a literature review and implications. Psychol Mark 33(12):1029-1038

Archer, B. (1981). A view of the nature of design research. Design: science: method. Westbury House, Guildford, UK

Artusi F, Bellini E (2020) Design and the customer experience: the challenge of embodying new meaning in a new service. Creat Innov Manag 29(S1):152-161

Bagozzi RP (1974) 'Marketing as an organized behavioral system of exchange. J Mark 38(October):77-81

Banting PM, Ross RE (1973) The marketing mix: a Canadian perspective. J Acad Mark Sci 1:1-11

Bartels R (1968) The general theory of marketing. J Mark 32(1):29-33

Bartels R (1951) Can marketing be a science? J Mark 15(3):319-328

Baumgarth C, Bahati Wieker J (2020) From the classical art to the urban art infusion effect: the effect of street art and graffiti on the consumer evaluation of products. Creat Innov Manag 29(S1):116-127

Berkowitz M (1987) Product shape as a design innovation strategy. J Prod Innov Manag 4(4):274-283

Berry LL (1995) Relationship marketing of services-growing interest, emerging perspectives. J Acad Mark Sci 23(4):236-245

Beverland MB (2005) Managing the design innovation-brand marketing interface: Resolving the tension between artistic creation and commercial imperatives. J Prod Innov Manag 22(2):193-207

Beverland MB, Gemser G, Karpen IO (2017) Design, consumption and marketing: outcomes, process, philosophy and future directions. J Mark Manag 33(3/4):159-172

Bloch PH (2011) Product design and marketing: Reflections after fifteen years. J Prod Innov Manag 28(3):378-380

Brown LO (1948) Toward a profession of marketing. J Mark 13:27-31 
Brown T (2008) Design thinking. Harv Bus Rev 86(6):84-92

Bruce M, Daly L (2007) Design and marketing connections: creating added value. J Mark Manag 23(9-10):929-953

Carvajal Pérez D, Le Masson P, Weil B, Araud A, Chaperon V (2020) Creative heritage: overcoming tensions between innovation and tradition in the luxury industry. Creat Innov Manag 29(S1):140-151

Chen CL (2021) Cultural product innovation strategies adopted by the performing arts industry. Rev Manag Sci, in print.

Choffray JM, Lilien GL (1978) Assessing response to industrial marketing strategy: an operational structure for use in making decisions on product design and communication programs. J Mark 42(2):20-31

Coco N, Calcagno M, Lusiani M (2020) Struggles as triggers in a design-thinking journey. Creat Innov Manag 29(S1):103-115

Creusen ME, Schoormans JP (2005) The different roles of product appearance in consumer choice. J Prod Innov Manag 22(1):63-81

Cross N (1982) Designerly ways of knowing. Des Stud 3(4):221-227

De Wulf K, Odekerken-Schröder G, Iacobucci D (2001) Investments in consumer relationships: a crosscountry and cross-industry exploration. J Mark 65(4):33-50

d'Ippolito B (2014) The importance of design for firms' competitiveness: a review of the literature. Technovation 34(11):716-730

Gilal NG, Zhang J, Gilal FG (2018) Linking product design to consumer behavior: the moderating role of consumption experience. Psychol Res Behav Manag 11:169-185

Graesch JP, Hensel-Börner S, Henseler J (2020) Information technology and marketing: an important partnership for decades. Ind Manag Data Syst 121(1):123-157

Hair JF, Howard MC, Nitzl C (2020) Assessing measurement model quality in PLS-SEM using confirmatory composite analysis. J Bus Res 109:101-110

Hemonnet-Goujot A, Abecassis-Moedas C, Manceau D (2020) When external design and marketing collaborate to develop new products: typology of patterns. Creat Innov Manag 29(S1):51-62

Henseler J (2017) Bridging design and behavioral research with variance-based structural equation modeling. J Advert 46(1):178-192

Henseler J, Schuberth F (2020) Using confirmatory composite analysis to assess emergent variables in business research. J Bus Res 120:147-156

Huertas MK, Pergentino I (2020) The effect of "cocreation with consumers" claims on purchase intention: the moderating role of product category performance information. Creat Innov Manag 29(S1):75-89

Hutchinson KD (1952) Marketing as a science: an appraisal. J Mark 16(3):286-293

Idemen E, Elmadag AB, Okan M (2020) A qualitative approach to designer as a product cue: proposed conceptual model of consumers perceptions and attitudes. Rev Manag Sci, in print.

Kotler P, Levy SJ (1969) A new form of marketing myopia: rejoinder to Professor Luck. J Mark 33(3):55-57

Kotler P, Murray M (1975) Third sector management: the role of marketing. Public Adm Rev 35(5):467-472

Kotler P, Rath GA (1984) Design: a powerful but neglected strategic tool. J Bus Strat 5(2):16-21

Krohn M (2015) Strategically integrated design-helping brands to keep their promises. Mark Intell Rev $7(2): 28-33$

Kumar V (2009) A process for practicing design innovation. J Bus Strateg 30(2/3):91-100

Laroche M, Habibi MR, Richard MO (2013) To be or not to be in social media: How brand loyalty is affected by social media? Int J Inf Manage 33(1):76-82

Levy SJ, Czepiel J (1974) Marketing and aesthetics. In: Curban RC (ed) Combined Proceedings, Series 36. American Marketing Association, Chicago, IL, pp 386-391

Liu Y, Soroka A, Han L, Jian J, Tang M (2020) Cloud-based big data analytics for customer insightdriven design innovation in SMEs. Int J Inf Manage 51:102034

Luchs MG, Swan KS, Creusen ME (2016) Perspective: a review of marketing research on product design with directions for future research. J Prod Innov Manag 33(3):320-341

Luck DJ (1969) Broadening the concept of marketing. Too far. J Mark 33(3):53-55

McCarthy, E. J. (1978). Basic Marketing: A Managerial Approach. RD Irwin.

Mokwa MP, Nakamoto K, Enis BM (1980) Marketing management and the arts. In: Mokwa MP, Dawson WM, Prieve EA (eds) Marketing the Arts. Praeger, New York, pp 14-28 
Motta-Filho MA (2020) Brand experience manual: bridging the gap between brand strategy and customer experience. Rev Manag Sci, in print.

Mulder-Nijkamp M (2020) Bridging the gap between design and behavioural research: (re)searching the optimum design strategy for brands and new product innovations. Creat Innov Manag 29(S1):11-26

Nagel C, Schumann J (2020) Post-adoption buffering effects of innovative product aesthetics. Creat Innov Manag 29(S1):128-138

Österle H et al (2011) Memorandum on design-oriented information systems research. Eur J Inf Syst 20(1):7-10

Overdiek A, Warnaby G (2020) Cocreation and codesign in pop-up stores: The intersection of marketing and design research? Creat Innov Manag 29(S1):63-74

Palos-Sanchez P, Saura JR, Correia MB (2021) Do tourism applications' quality and user experience influence its acceptance by tourists? Rev Manag Sci, in print.

Peterson RA (1980) Marketing analysis, segmentation, and targeting in the performing arts. In: Mokwa MP, Dawson WM, Prieve EA (eds) Marketing the arts. Praeger, New York, pp 182-200

Rothwell R, Gardiner P (1983) The role of design in product and process change. Des Stud 4(3):161-169

Scholz T, Redler J, Pagel S (2020) Re-designing adaptive selling strategies: the role of different types of shopping companions. Rev Manag Sci, in print.

Schuberth F (2021) Confirmatory composite analysis using partial least squares: setting the record straight. Rev Manag Sci, in print.

Sette G, Brito PQ (2020) To what extent are digital influencers creative? Creat Innov Manag 29(S1):90-102

Shapiro BP (1974) Marketing in nonprofit organizations. J Volunt Action Res 3(3-4):1-16

Walsh V (1996) Design, innovation and the boundaries of the firm. Res Policy 25(4):509-529

Wu D, Rosen DW, Wang L, Schaefer D (2015) Cloud-based design and manufacturing: a new paradigm in digital manufacturing and design innovation. Comput Aided Des 59:1-14

Xue J, Swan KS (2020) An investigation of the complementary effects of technology, market and design capabilities on exploratory and exploitative innovations: evidence from micro and small-sized techenterprises in China. Creat Innov Manag 29(S1):27-50

Publisher's Note Springer Nature remains neutral with regard to jurisdictional claims in published maps and institutional affiliations. 